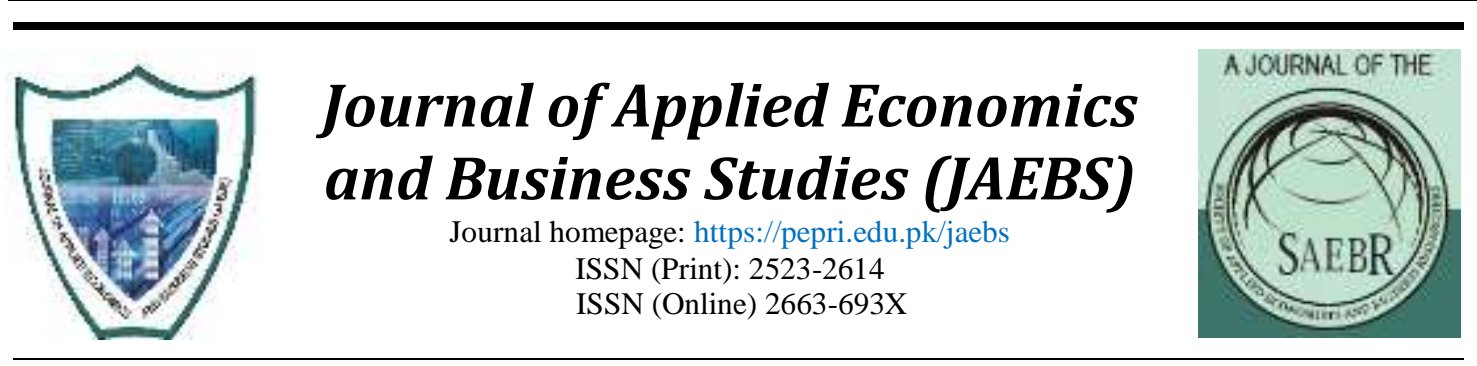

\title{
Exploring the Approaches to Measure the Value of Household Work: An Experience from Pakistan
}

\author{
Hamna Nasir ${ }^{*}$, Ambreen Fatima ${ }^{2}$ and Shaista Alam ${ }^{3}$ \\ ${ }^{1} \mathrm{PhD}$ student at Applied Economics Reseach Center (AERC), University of Karachi \\ ${ }^{2}$ Associate Professor at Applied Economics Research Center (AERC), University of Karachi \\ ${ }^{3}$ Associate Professor at Applied Economics Research Center (AERC), University of Karachi
}

\begin{abstract}
The purpose of this research is to fill the gap in the knowledge by estimating the value of time spent on household work especially by women i.e study aims to assess the economic worth of time. Specifically, the objective of this research is to estimate the value of time using two approaches, the one estimating opportunity cost and the other estimating the market price/value of household work. The value of time is estimated for different types of household activities. In addition, the study also assesses the determinants responsible for accelerating the opportunity cost and market value of time during the past three decades in Pakistan as well critically study assess why the household is not diverting its human capital towards the paid employment though the value of time has increased substantially. The determinants mainly focus on personal and demographic characteristics as these factors are responsible to keep the individuals engaged in household activity. The determinants are explored using Pooled OLS. Results show that the opportunity cost of household work performed by male and female worth around Rs.26,082/week and Rs.155,126/week; whereas the market price of male and female are estimated around Rs.22,908/week and Rs.63,813/week respectively. Further, the results of this study confirm that the opportunity cost of all non-market activities is greater than the market value indicating that the work performed by individual at home(necessary to be performed) should be recognized as it has substantial economic worth. Hence this research contributes to knowledge by enhancing the understanding of policymakers about the economic contribution made especially by women through household work - that often remain unaccountable.
\end{abstract}

* hamnainfinite@gmail.com

This paper is part of PhD Thesis under process.

Keywords

Labor

Economics, Economics of Gender, Household Economics, Opportunity Cost

JEL Classification J01,J16, D13, J17 
Hamna Nasir, Ambreen Fatima and Shaista Alam

"In past, some of the resistance to further work on this subject came from believe that "invaluable" contribution of homemaker would be demanded by being assigning a monetary value. It is however the failure to assign a price for the services of the homemaker which has tended to convey the impression that they are valueless rather than priceless [Marianne (1980) pp -387]."

\section{Introduction}

According to the Labour Force Survey (LFS) of Pakistan, 2017-18 on average nonmarket work hours of women in the rural region are 40 hours/week and in the urban region, it is around 43 hours/week, whereas the average non-market hours of male work in the rural region is 7 hours/week and in the urban region, it is 6 hours/week only. Though Becker (1965) emphasized estimating the opportunity cost of time. He noted that the time allocated to non-market work (household work) worth more (if its economic value is estimated) for economic welfare than market time. The argument placed by Becker is that the substantial time per week allocated to household work, is hence considered as an investment for the economic and social welfare of the country.

Economists have made many valiant efforts to estimate the dollar value of nonmarket work (household work). The value of household work is usually not accounted for in the calculation of GDP nor is it taken into account when the income of the household is considered. The value is mainly not accounted for because of the measurement issues. This study highlights the measurement issue regarding the economic contribution of the non-market work made in Pakistan. The purpose of this research is twofold - to gain an understanding of the nature of non-market work performed by individuals in Pakistan and to estimate the economic worth/value of that work. Precisely study estimates the economic worth of activities that took place within the household. Non-market work here refers to those domestic activities that are performed by women mainly and by men occasionally for which they receive no remuneration.

A review of past studies shows that time allocated to non-market work is usually underestimated as the economic value of time is not easy to measure/calculate. For example, research on intrahousehold bargaining power assumed that time allocated to domestic work is a necessity, and the household members with the least power or low opportunity cost of time in the market forces to allocate their time to home production. The opportunity cost of housework for women is high therefore a large segment of the society (females) remained deprived and is not allowed to play its role properly in the labour market. A general assessment shows that domestic work is "undervalued, underpaid, unprotected and poorly regulated" and if done by women it is "unrecognized" in spite of the contributions made. Their work is never considered in the national accounting system. It leads to prejudice against individuals who perform domestic chores which indicates that the work performed by them at home (necessary to be performed) should be recognized as it has substantial economic worth. The 
activities for which people receive the compensation provide benefit to the economy, while the unpaid activities have remained economically meaningless. Further, most of the international studies have focused on the economic value of household work, whereas studies in Pakistan by Sultana and Nazli (1994) and Saqib and Arif (2012) have mainly focused on time allocated to paid market work and household work - not fully considering the economic worth of non-market activities performed within the household. According to past studies addressed by Khan (2007), Bhalotra \& Attfield (1998), Naqvi et al. (2002) and Syed et al (2013) household responsibilities, labor market discrimination, customs, and traditions are some of the factors which draw female participation from the paid market work. The only study for Pakistan has been conducted by Arshad (2008) who has investigated the market price of household activities.

Considering the arguments raised in earlier studies, the specific objective of this research is to estimate the opportunity cost of non-market work hours for a number of activities. These activities include: within household light construction work, such as mud plaster of roofs and walls, construction and repair of boundary walls, rooms, collection of firewood or cotton sticks for use as firewood for household consumption, bringing water, taking food from house to farm, sewing pieces of cloth or leather, knitting, embroidery, mat, rope making, ginning, spinning and weaving, shopping and marketing, washing, mending or pressing clothes, child care/care of adult, child education, house cleaning, and cooking. Further, this study also makes an assessment of factors responsible for accelerating the opportunity cost of time allocated to nonmarket work by individuals in the past few years therefore critically study assess why the household is not diverting its human capital towards the paid employment though the value of time has increased substantially. In order to assess the determinants of opportunity cost and the market price of non-market work, personal and demographic characteristics are explored as these factors are responsible to keep the individuals engaged in household activity. Personal characteristics include; age, experience, marital status, education attainment, while demographic characteristics include the number of children and adults, household income, regional and provincial dummies.

In order to evaluate the above-stated objectives, this study extracted the data from the Labor Force Survey (LFS) of Pakistan for various years. Further, to assess the opportunity cost and market price of household work a number of techniques are applied, whereas Pooled OLS is used for empirical assessment.

This research hence fills the gap in the knowledge by exploring the time individuals spent on non-market work and its economic worth. Moreover, it assesses the contribution made by an individual in the social development of the country through performing non-market work. Further, the role of women in the economy is recognized by society only when they participate in the paid labor force, their non-market work remains hidden and unacknowledged and the double burden on women is often not 
addressed. The importance of non-market work though have some recognition but it is limited to children and elder-care. This study raised some thought-provoking points by assessing the economic value of non-market work in Pakistan.

Overall, the study recommends that the contribution of women's household work if highlighted in GDP and other measures of national wealth it would help in raising their status and promoting gender equality in Pakistan - ultimately reducing poverty. Further, to achieve the target set in SDG goal 5.4 this study recommends that awareness should be raised about women's contribution to national wealth - i.e. highlight the economic value of their work.

This paper is organized as follows: Section 2 provides a theoretical foundation; section 3 discusses the methodology; in section 4 data sources and model specification are discussed and in section 5 the opportunity cost and market price of non-market work are detail assessed by using a number of techniques and its determinants are also explored for assessment purpose. The last section contains the conclusion and policy implications.

\section{Theoretical Foundations}

Reid (1934) was the pioneer to estimate the monetary value of home production. Since then many scholars have attempted to estimate the monetary value of household work with the aim to evaluate unpaid domestic and care work and integrate it with the System of National Accounts - the so-called "Satellite Accounts". As a result, in the national economic accounts, the economic activities are now categorized as:

(i) System of National Accounts (SNA) production activities.

(ii) Non-SNA production activities (food preparation, childcare, elder care, making and care of textiles, upkeep of dwelling and surroundings, repairs and maintenance of dwelling and of household equipment, household management and shopping, gardening, and pet care) and unpaid work for the community

(iii) Non-economic activities some times called personal activities (physiological and recreational activities and self-education).

Reid (1934) wrote in her famous book on "Economics of Household Production" that: "the integral part of our whole economic system is household. If we become aware of labor costs and productive activities which are necessary to maintain the present standards of living. Unless this is done, we cannot rightly appraise the economic role of home-keeping women or act intelligently in matters concerning the gainful employment of married women. Nor can we understand home problems and formulate satisfactory curricula of education for home and family life."

Stoetzel (1948) and Girard (1958), using time-based studies conducted in France for the year 1950, provided an improved knowledge of the amount of household work 
which is performed by women engaged in paid labor and as full-time housewives. Their detailed analysis provided evidence of the main factors which bear the volume of household work performed. The rational decisions made by individuals without constraints with respect to the number of hours spent on market work and if they have full knowledge of potential earnings than the individuals who are not engaged in market work would value their time at home as much or more than the opportunity cost i.e. alternative forgone. Therefore, their potential earnings would provide a lower limit but would not measure the worth of home time, this could be higher and could fluctuate considerably while potential earnings remain the same or change in the opposite direction.

The value of housework in terms of the number of hours spent presents certain advantages. For instance, it allows direct comparison between total quantities of work supplied in market and household sectors, the need for fictitious imputation of money values is obviated to the latter, as the unit of measure and hours of work are common in both (Fourastit 1965).

Hawrylyshyn (1976) stated that the idea behind the valuation of household activities was "to replace not the mother - homemaker, but merely a portion of her services" (p.112). The notion stated that "the market cost method was closest to the concept of the dollar value of household services". He concluded that valuation resulting from the estimation is around one-third of GNP on average.

To value the household services various estimates were put forward by Hawrylyshyn (1976). There exists wide variability in the results obtained, attributed to each approach. Among the methods discussed, the highest value obtained is related to the opportunity cost approach estimated for women involved in paid employment, the lower value is obtained from the method based on the price of a single housekeeper and the least value is obtained from the method which is based on pricing individual services. Family size, wife's market-work status, and age of the youngest child are factors that affect very strongly the value of services performed. According to the results, the value of total household services must include the contribution of spouse and children, although the contribution of a wife is dominant.

He also concluded that the valuation of the opportunity cost method has an upward biased relative to the market cost method. He argued that the reason for this upward bias was due to comparable levels of home production in separate households which would produce different values if the individuals in each household had different marketable wages. The report surveyed by Hawrylyshyn attempts to value household services which neither improved the accuracy nor quelled the debate regarding appropriate methods that estimate the value of home production.

Hawrylyshyn (1977) considering the value of non-market time stated that "in equilibrium, the value of time spent at home equals its opportunity cost which clearly 
is, its wage on the market". The rational household therefore will apply the optimization rule by using the factor "time" to the point where its marginal product equals its price. Therefore, households' own estimation is done for a non-market time at the margin which is equal to its market hourly wage. Since the work of Hawrylyshyn (1976 and 1977) measuring productive household activities in monetary terms become a field of study. However, It was argued by Peterson (1978) that these methods overestimate home production whereas Bell and Taub (1982) argue that current valuation methods understate the true value of household production.

Further, the authors have emphasized over conceptualizing the household production method and various methodological approaches for its evaluation. Their evaluation, based on time use surveys, induces thought on time division between different kinds of activities - categories. The classification helps to clarify the concept of housework and also emphasizes the economic and social role of women inside and outside the market sector (Szalai 1972 and Michel 1978).

Ferber and Birnbaum (1980) conclude that to value housework, the market cost approach is preferable to the opportunity cost approach and general household keeper's wages are preferable over specialized wages as individuals enjoying specialized wages usually performed a variety of household tasks.

Quah (1986) explains that household production is a non-market activity and its estimation is difficult, therefore its benefits cannot be measured by survey or observation. To estimate how much production at home contributes to total production taking place in an economy one must compute it indirectly, though these attempts produce a myriad of quantitative results and none of these have shown promise as a direct and sensible approach to value household production. the two fundamental approaches are used to value household production (i) the opportunity cost approach emphasizes the time devoted to household production and a value is set for such production as an individual could earn income in the market, whereas it can be measured from services which can be purchased from the market and (ii) the market price approach - household activities are valued as a "market price" of hiring someone who could perform these tasks. It is argued by Murphy (1978) that both methods produce significantly different results. Time devoted to household production refers to productive activities as it has an economic value, while the time devoted to biological and non-productive leisure activities are not valued. Chiswick (1982) and Wolf (1986) indicated that the market cost method is preferable to the opportunity cost method since the latter method is over biased. Whereas, it was observed by Murphy (1978) that as compared to the market cost method opportunity cost method is not significantly upward biased. Becker (1985) considered a household as a small factory in which every individual specializes in the task that he or she can fulfill most efficiently. So, the relative importance determines who is going to perform unpaid work and who is going for paid work. Further, human capital theory and based on the market income it is 
considered rational for the individuals who have high hourly wage and the high opportunity cost of work at the market should perform market work.

Further, according to the Canadian National Account System "information on unpaid work can serve i) to monitor and describe more completely how resources are used; ii) to foster a greater understanding of the economy and of the links between its market and non-market sectors; iii) to provide information on what types of work are undertaken, what goods and services result; what costs are incurred, who provides benefits; and $i v)$ to inform the public debate and help in the formulation of public policy" [extracted from "Households' Unpaid Work: Measurement and Valuation" published by Statistics Canada (1995)- Studies in National Accounting].

The issue of women's economic contribution by valuing their unpaid labor was raised by many scholars, activists, and others for Canada, United States, New Zealand, and for many other countries. Studies have investigated its scale and estimated the value of women's unpaid work particularly in the domestic sphere (Shamim 1996).

Recently, Folbre (2009) explains that as more women are involved in the labour market the amount of time spent on unpaid work is reduced, whereas men do not make up the slack. Living standards are lower than GDP which suggests that more income is spent on purchasing food away from home, housekeeping, child, and elder care services that were provided outside the market. Living standards and economic welfare do not depend on family income but depend on the amount of time people devote to unpaid work. Heymann and Beem (2005) explain that as women are more involved in the labour market they usually find low-paid work and usually their children suffer.

Only earned income is valued by society, while no assistance is provided by the society on the performance of other duties and difficulties faced by household members for which little/no support has been received by employers or state to balance between work and family responsibilities. For Pakistan, Arshad (2008) found out that a Pakistani woman no matter what region they belong to perform a wide variety of tasks. They work 16 hours/day including major and supplemental tasks. Most of them do not have any leisure time and they utilize their spare time to complete household chores. It has become clear from this research that women have taken up most of the household responsibilities without any support. Even if they have a servant, rearing and assessing children with their school work and cooking is done by women herself. They recognize that their household activities have value, though they would be surprised at the magnitude of their economic worth. When household activities are outsourced the value calculated by researchers shows that it cost Rs $48,000 /$ year or US $\$ 8,002$ in urban areas, while in a rural area it cost Rs. 25,800/year or US\$430.

From the review of the above literature, it can be concluded that researchers have paid little attention to household activities. Though research on household activities is currently at the center of theoretical or policy debates but much emphasis is paid on the 
approach. The literature has overlooked activities taking place within the household (such as food preparation, child care, and other domestic chores) as well as the division of labor by age and sex are the neglected areas of research, especially in the case of Pakistan.

\section{Methodology}

In this article two approaches; opportunity cost and market pricing approach are used to evaluate the worth of home production. The market price method is preferred in literature if the purpose of a valuation is to incorporate estimates into national income accounts. The opportunity cost method, however, is preferable if the purpose is to compensate for welfare loss.

\section{A. Opportunity Cost Method}

The opportunity cost method is itself evolved in literature through many approaches. The below section elaborates on two different techniques employed in this study to estimate the opportunity cost of non-market work.

According to Hamdad (2003) "when an individual engages in non-market work, s/he has to sacrifice activities that could have been done instead, along with all associated monetary and non-monetary benefits".

\section{i) James (1996) and Pandey (2001)}

In this method, authors have incorporated the wage rate as the opportunity cost of time which is formalized as:

\section{Opportunity value of non-market work= (total number of hours/week devoted to non-market work * individual's minimum weekly wage rate $^{\mathbf{1}}$ )}

\section{ii) Efroymson (2010)}

This method was given by Efroymson (2010) for evaluating the value of non-market activities. The opportunity cost of non-market work is estimated by hours/week spent on each activity multiplied by the minimum weekly wage.

\section{Opportunity Cost of Household Work $=($ Value of non-market work for each activity) * (Hours allocated to each activity)}

Here the subscript i represents the non-market activities.

\section{B. Market Price Method}

The second method of valuing non-market work/week is market price. In this method, it is assumed that the time spent on non-market activities by household

\footnotetext{
${ }^{1}$ Minimum wage rate is used because wages of household workers and unpaid contributing family workers is not available, therefore minimum wages are used. 142
} 
members is valued by the earning level of other people who are engaged in similar activities. It is assumed that household members and their "replacements" are "equally productive and responsible". Likewise, the opportunity cost method; the market price method employed in this study, is also estimated using two different approaches.

\section{i) Global Substitute approach}

Global Substitute approach can be defined as "a general housekeeper who is chosen as a substitute for all non-market work that household members actually do."

The global substitute method (GL) is given by Chadeau (1992) and is formalized as:

Where:

$$
H W=\sum\left(T_{i} * W\right)
$$

HW represents the non-market work

Ti represents time spent on non-market work by the person i per week

$\mathrm{W}$ is the wage rate of a person trained in general housekeeping duties/household keeper

ii) Specialist Substitution Approach

The specialist substitution method is defined as "a variety of trained workers who are chosen as substitutes to perform those tasks at home which correspond to specialization in the labor market". It includes cooks, domestic cleaners, etc.

The specialist substitute method (SP) is also given by Chadeau (1992) and it is formalized as:

$$
H W_{i}=\sum_{i} \sum_{j}\left(T_{i j} * W_{i}\right)
$$

Where

- $\mathrm{T}_{\mathrm{ij}}$ represents time spent on performing non-market activities $\mathrm{i}$ by person $\mathrm{j}$ per week.

- $\mathrm{W}_{\mathrm{i}}$ is the wage rate of a specialist worker performing task $\mathrm{i}$ (or its closest substitute) in the market.

\section{Model Specification and Data Sources}

The substantial increase in non-market work hours during 1994-95 to 2017-18 for both gender has raised the opportunity cost and market value of non-market value as well. The raised value if not properly socially and economically acknowledge performing these activities will be looked down and individual moves towards paid activities - the recognized activities. The accelerated value of non-market hours of work has grown $2.84 \%$ for females and declined for males by $2.26 \%$ (see table 1) needs a detailed assessment of factors not encouraging individuals for having paid work though the opportunity cost and market value has increased substantially. This is mainly because the higher the responsibility of an individual at home lower will be his/her participation 
in the labor market and hence higher will be the opportunity cost of time. In order to estimate the factors determining the accelerating value of non-market work for the past few decades following simple models are estimated. Specifically, the model for estimating the determinants of opportunity cost and the market price of non-market work are formulated as:

$$
\begin{gathered}
O C_{\text {hhwrkg }}=\alpha_{0}+\alpha_{1} D C+\alpha_{2} P C+\alpha_{3} \text { Region }+\alpha_{4} \text { Province }+\alpha_{5} H H Y+\theta_{0}(I) \\
\left.M K_{\text {hhwrkg }}=\beta_{0}+\beta_{1} D C+\beta_{2} P C+\beta_{3} \text { Region }+\beta_{4} \text { Province }+\beta_{5} H H Y+\emptyset_{0} \_ \text {(II }\right)
\end{gathered}
$$

Where $O C$ represents the opportunity cost of non-market work, $M K$ represents the market price of non-market work and subscript hhwrk represent the household work and $\mathrm{g}$ represents gender. $D C$ represents demographic characteristics such as children less than 6 years, adults above 65 years, family size, etc. $P C$ represents personal characteristics which are age, age ${ }^{2}$, education, marital status, etc. The dummies capturing Regional and Provincial variation influene non-market hours of work. $H H Y$ represents dummy of household activities and number of years.

$O C$ and $M P$, dependent variables, are measured in $\mathrm{PKR} /$ week. $O C$ is estimated by the method proposed by James (1996) and $M P$ is estimated by using the Global substitute method proposed by Chadeau (1992). In this study, the opportunity cost and market price across gender and for different household activities are examined in detail. Overall, the average opportunity cost of household work for a female is Rs.155,126/week and for males is Rs.26,082/week; whereas the market price of household work for the male is Rs. 19,655/week and that of the female is Rs.74, 714/week.

As far as explanatory variables are concerned, starting with the personal characteristics, age may have a positive effect on $O C$ and $M P$ as with the increase in age the household responsibilities of individuals also increases leading to an increase in household work hours ultimately declining the paid market hours of work which lead to increase in $O C$ and $M P$. Experince proxied here by squaring the age hypothesized to have a negative effect on $O C$ and $M P$ of household work as after a certain age with the increase in age domestic responsibilities are shifted to the younger generation. This also traces out the possible non-linearity in the variable.

Years of education may have both a positive or negative effect. It may have a negative effect due to their increased participation in labour market - educated females prefer paid market work. Due to the increased participation of females in the labor market, some household work is outsourced which increase MP and declines OC. Contrary to it, years of education may have a negative effect as most of the household responsibilities are endured by women family members whether they are highly educated or illiterate since the value of time at home has increased substantially as it is 
mandatory to be performed by them instead of being engaged in paid market work, hence OC increases and MP decreases. Whereas years of education may have a negative effect on OC and MP on male work as they diversified opportunities are available for them to make use of their education.

Whatever the marital status of women is, household work is customary and obligatory for them, therefore their $O C$ and $M P$ are higher as this work is necessary, therefore it should be recognized. Contrary to this, most of the household chores are performed by females that decline the market prices of domestic workers hence lower the $M P . O C$ and $M P$ are lower as mainly females work as low paid domestic helpers to support their families. Further, $O C$ and $M P$ of males may have negative relation with their marital status of being married like most of the household tasks are performed by females both at home and in the market and males are the main economic providers therefore their non-market work hours are lower, hence $O C$ and $M P$ are low.

As the non-market work hours are mostly influenced by the family composition hence demographic variables considered here are mainly focusing on dependency ratio. The number of dependents, here, is represented by the children under the age of 6 , children between the age of 6-10, children between the age of 11-14, and adults above the age of 65 . As the number of dependents increases in a household the opportunity cost and market price of female non-market work increases. Whereas the increase in the number of dependents may decline the opportunity cost and market price of male work as they are responsible for supporting their families hence their paid market work hours are usually higher than the non-market hours of work.

Household income may have a positive effect on $O C$ as the socio-economic condition of the household become better, therefore paid working hours of female decline while their non-market hours' increases, whereas the paid work hours of males will increase and their non-market hours will decline. Contrary to this, it may have a negative effect on $O C$ and $M P$ as most of the household chores could be performed by maids or home saving appliances could be purchased - the affordability of support workers increases with the increase in income. Specifically, household income may have a positive effect on the $M P$ as household start outsourcing the domestic task.

Across the region, the urban region is taken as a reference category. $O C$ of household work may be lower, whereas MP of housework may be higher in the urban region due to the availability of domestic helpers/ outsourcing of domestic chores and higher participation of females in the labour market. Specifically, the OC of household work may be positive and MP of household work may be negative, if most of the household chores are performed by individuals due to vilest social conditions.

Across the provinces, KPK is taken as a reference category. $O C$ and $M P$ of household work may be positive or negative depending on the customs and traditions of the province. Across the household activities, some are time-intensive and therefore 
Hamna Nasir, Ambreen Fatima and Shaista Alam

it may have a positive effect on OC and MP of household work and some may have a negative effect on OC and MP of household work.

The data used in this study is taken from the Labor Force Survey (LFS) of Pakistan for the years 1994-95, 1999-2000, 2006-07, 2014-15, and 2017-18, which is conducted by the Pakistan Bureau of Statistics ${ }^{2}$ (PBS).

\section{Results}

The result section is divided into two subsections; the first one provides a descriptive assessment while the second one will make the empirical assessment of the model.

\section{a. Descriptive Statistics}

For assessing the opportunity cost of non-market work per week different techniques are applied as described above. Specifically, the monetary value of non-market work is estimated based on opportunity cost (the household's average income) and replacement cost (the housekeeper cost method). In this section opportunity cost and market value of non-market work are discussed in detail.

\section{A. Assessment of Opportunity Cost of Non-Market Work}

The opportunity cost of non-market work when analyzed by minimum wage as given by James (1996) across years (see Table 1) shows that the value of non-market work of female is higher than male. The opportunity cost of female work has increased from Rs.13,928 to Rs.155,126 per week - around 2.53 annual growth; whereas for male work it has increased from Rs. 4,778 to Rs. 26,082 per week with annual growth around 1.49. Over the years the minimum wage has also increased (2.25 annual growth in minimum wage), therefore the opportunity cost of non-market work has also increased for both genders.

\section{Table 1: Opportunity Cost of Household Work/Week}

\begin{tabular}{|l|c|l|c|r|}
\hline \multicolumn{1}{|c|}{ No. of Years } & $\begin{array}{c}\text { Male } \\
\text { Hours/Week }\end{array}$ & $\begin{array}{c}\text { Male OC of HH } \\
\text { Work/Week }\end{array}$ & $\begin{array}{c}\text { Female } \\
\text { Hours/Week }\end{array}$ & $\begin{array}{c}\text { Female OC of } \\
\text { HH Work/Week }\end{array}$ \\
\hline $1994-95$ & 0 & Rs0 & 37 & Rs13,928 \\
\hline $1999-00$ & 8 & Rs4,778 & 40 & Rs 25,212 \\
\hline $2006-07$ & 7 & Rs7,978 & 38 & Rs123,759 \\
\hline $2014-15$ & 6 & Rs17,477 & 41 & Rs155,126 \\
\hline $2017-18$ & 7 & Rs26,082 & 41 & \\
\hline $\begin{array}{l}\text { Growth Rate in } \\
\text { Hours/Week }\end{array}$ & -2.257 & & 2.844 & 2.534 \\
\hline Growth in OC & & 1.486 & & \\
\hline
\end{tabular}

\footnotetext{
${ }^{2}$ Since the Labor Force of Pakistan is a published data, therefore questionnaire and the detail of Labor Force Survey of Pakistan is available on the website of Pakistan Bureau of Statistics and it can be downloaded from www.pbs.gov.pk 146
} 
Further to this, the opportunity cost of non-market work/week by activities is presented in table 2 by gender. Opportunity cost of all non-market activities has increased over the years. Specifically, over the years it has been observed that the opportunity cost of child care and cooking activities remains higher as compared to the opportunity cost of other non-market activities. The opportunity cost of child care, child education, and cooking (if performed by females) has increased from Rs. 3,960/week to Rs. 45,000/week, Rs. 3041/week to Rs. 26,250/week and Rs. 5,095/week to Rs. $60,000 /$ week. As these activities are time-intensive, therefore its opportunity cost is also higher. Cooking hours have grown by $4.44 \%$ and its annual growth is around 2.69. The opportunity cost of sewing, house cleaning, and washing has also increased from Rs. 2,587/week to Rs. 20,505/week, Rs. 3,248/week to Rs. 30,000/week and Rs. 2,876/week to Rs. 26,250/week respectively. Moreover, the opportunity cost of shopping and marketing, firewood collection, fetching water, and construction work performed by females has increased from Rs. 2,220 to Rs.15,000/week, Rs.2,425 to Rs.17,776/week , Rs.2,780 to Rs.20,715/week and Rs.2,154 to Rs.13,978/week.

However, these activities if performed by males the opportunity cost remains higher only for shopping and marketing activity as compared to other activities. The opportunity cost of shopping and marketing, firewood collection, fetching water, and construction work have increased from Rs.3,438/week to Rs.22,500/week, Rs.4,524/week to Rs.20,291/week, Rs.4,212 to Rs.18,675/week, and Rs.4,183 to Rs.12,500/week. Hours of firewood collection have declined by $9.524 \%$ and its annual growth is around 1.16. The annual growth in opportunity cost for all activities shows an increasing trend due to the increase in the minimum wage over the years, whereas growth rate of household hours for some activities have declined over the years.

\section{Table 2: Opportunity Cost of Household Activities/Week}

\begin{tabular}{|l|l|r|r|r|r|}
\hline No.of Years & \multicolumn{1}{|c|}{ Household Activities } & $\begin{array}{c}\text { Male } \\
\text { House } \\
\text { hold } \\
\text { Hours/ } \\
\text { Week }\end{array}$ & $\begin{array}{c}\text { OC of Male } \\
\text { Household } \\
\text { Work/Week } \\
\text { (in PKR) }\end{array}$ & $\begin{array}{c}\text { Female } \\
\text { House } \\
\text { hold } \\
\text { Hours/ } \\
\text { Week }\end{array}$ & $\begin{array}{c}\text { OC of Female Household } \\
\text { Work/Week (in PKR) }\end{array}$ \\
\hline $1994-95$ & 0 & 0 & 7 & 2,502 \\
\hline & Sewing & 0 & 0 & 6 & 2,220 \\
\hline & Shopping \& Marketing & 0 & 0 & 8 & 2,875 \\
\hline & Washing\& Pressing Clothes & 0 & 0 & 11 & 3,960 \\
\hline & Child/Adult Care & 0 & 0 & 8 & 3,037 \\
\hline & Child Education & 0 & 0 & 9 & 3,248 \\
\hline & House Cleaning & 0 & 0 & 14 & 5,095 \\
\hline & Cooking & 0 & 0 & 6 & 2,425 \\
\hline & Firewood Collection & 0 & 0 & 7 & 2,780 \\
\hline & Fetching Water & 0 & 0 & 6 & 2,154 \\
\hline & ConstructionWork & 0 & 0 & 6 & 4,035 \\
\hline & Sewing & 6 & 3,438 & 5 & 3,378 \\
\hline & Shopping \& Marketing & 0 & 0 & 8 & 5,000 \\
\hline & Washing\& Pressing Clothes & 0 & 0 & 11 & 6,875 \\
\hline & Child/Adult Care & 0 & 0 & 8 & 5,000 \\
\hline & Child Education & 0 & 0 & 9 & 5,625 \\
\hline
\end{tabular}


Hamna Nasir, Ambreen Fatima and Shaista Alam

\begin{tabular}{|c|c|c|c|c|c|}
\hline & Cooking & 0 & 0 & 15 & 9,375 \\
\hline & Firewood Collection & 7 & 4,524 & 6 & 3,910 \\
\hline & ConstructionWork & 7 & 4,183 & 5 & 3,083 \\
\hline \multirow[t]{7}{*}{$2006-07$} & Sewing & 0 & 0 & 6 & 6,348 \\
\hline & Shopping \& Marketing & 6 & 6,942 & 5 & 5,750 \\
\hline & Washing\& Pressing Clothes & 0 & 0 & 7 & 8,050 \\
\hline & Child/Adult Care & 0 & 0 & 11 & 12,650 \\
\hline & Child Education & 0 & 0 & 7 & 8,050 \\
\hline & Fetching Water & 6 & 7,312 & 6 & 7,318 \\
\hline & ConstructionWork & 5 & 5,750 & 4 & 5,041 \\
\hline \multirow[t]{8}{*}{$2014-15$} & Sewing & 0 & 0 & 5 & 16,173 \\
\hline & Shopping \& Marketing & 5 & 14,857 & 5 & 15,000 \\
\hline & Washing\& Pressing Clothes & 0 & 0 & 7 & 21,000 \\
\hline & Child/Adult Care & 0 & 0 & 12 & 36,000 \\
\hline & Child Education & 0 & 0 & 7 & 21,000 \\
\hline & House Cleaning & 0 & 0 & 7 & 21,000 \\
\hline & Cooking & 0 & 0 & 16 & 47,963 \\
\hline & Firewood Collection & 6 & 16,941 & 5 & 15,515 \\
\hline \multirow{5}{*}{$2017-18$} & House Cleaning & 0 & 0 & 8 & 30,000 \\
\hline & Cooking & 0 & 0 & 16 & 60,000 \\
\hline & Firewood Collection & 5 & 20,291 & 5 & 17,776 \\
\hline & Fetching Water & 5 & 18,675 & 6 & 20,715 \\
\hline & Construction Work & 3 & 12,500 & 4 & 13,978 \\
\hline \multirow[t]{10}{*}{$\begin{array}{c}\text { Growth Rate in } \\
\text { Hours/Week }\end{array}$} & Sewing & 0 & & 3.0704 & \\
\hline & Shopping \& Marketing & 0 & & -8.105 & \\
\hline & Washing\& Pressing Clothes & 0 & & -2.1767 & \\
\hline & Child/Adult Care & 0 & & 3.4059 & \\
\hline & Child Education & 0 & & -3.3918 & \\
\hline & House Cleaning & 0 & & -1.9057 & \\
\hline & Cooking & 0 & & 4.4432 & \\
\hline & Firewood Collection & -9.524 & & -6.6774 & \\
\hline & Fetching Water & -9.524 & & -6.374 & \\
\hline & Construction Work & -19.048 & & -8.779 & \\
\hline \multirow[t]{4}{*}{ Growth in OC } & Sewing & 0 & & & 1.80 \\
\hline & Shopping \& Marketing & & 1.85 & & 1.44 \\
\hline & Washing\& Pressing Clothes & & 0 & & 2.03 \\
\hline & Child/Adult Care & & 0 & & 2.59 \\
\hline
\end{tabular}


Journal of Applied Economics and Business Studies, Volume. 4, Issue 4 (2020) 135-160 https://doi.org/10.34260/jaebs.447

\begin{tabular}{|c|l|c|c|c|c|}
\hline \multirow{2}{*}{ No.of Years } & Household Activities & $\begin{array}{c}\text { Male } \\
\text { House } \\
\text { hold } \\
\text { Hours/ } \\
\text { Week }\end{array}$ & $\begin{array}{c}\text { OC of Male } \\
\text { Household } \\
\text { Work/Week } \\
\text { (in PKR) }\end{array}$ & $\begin{array}{c}\text { Female } \\
\text { House } \\
\text { hold } \\
\text { Hours/ } \\
\text { Week }\end{array}$ & $\begin{array}{c}\text { OC of Female Household } \\
\text { Work/Week (in PKR) }\end{array}$ \\
\hline & Fetching Water & 1.14 & & \\
\hline & Construction Work & & 0.66 & & 1.61 \\
\hline
\end{tabular}

\section{B. Assessing Market Price of Non-Market Work}

The market price for non-market work is discussed in this sub-section.

Total non-market time (housework time) is valued at the housekeeper's market wage rate in GL method. It is evident from figure 1 that the market price of female work is more than male work. The market value of female housework has increased from Rs.9,275/week to Rs. 63,813/week; whereas for males, it has increased from Rs.5,376/week to Rs.22,908/week. Most of the non-market activities are performed by the female as domestic helpers; therefore her market price is also higher.

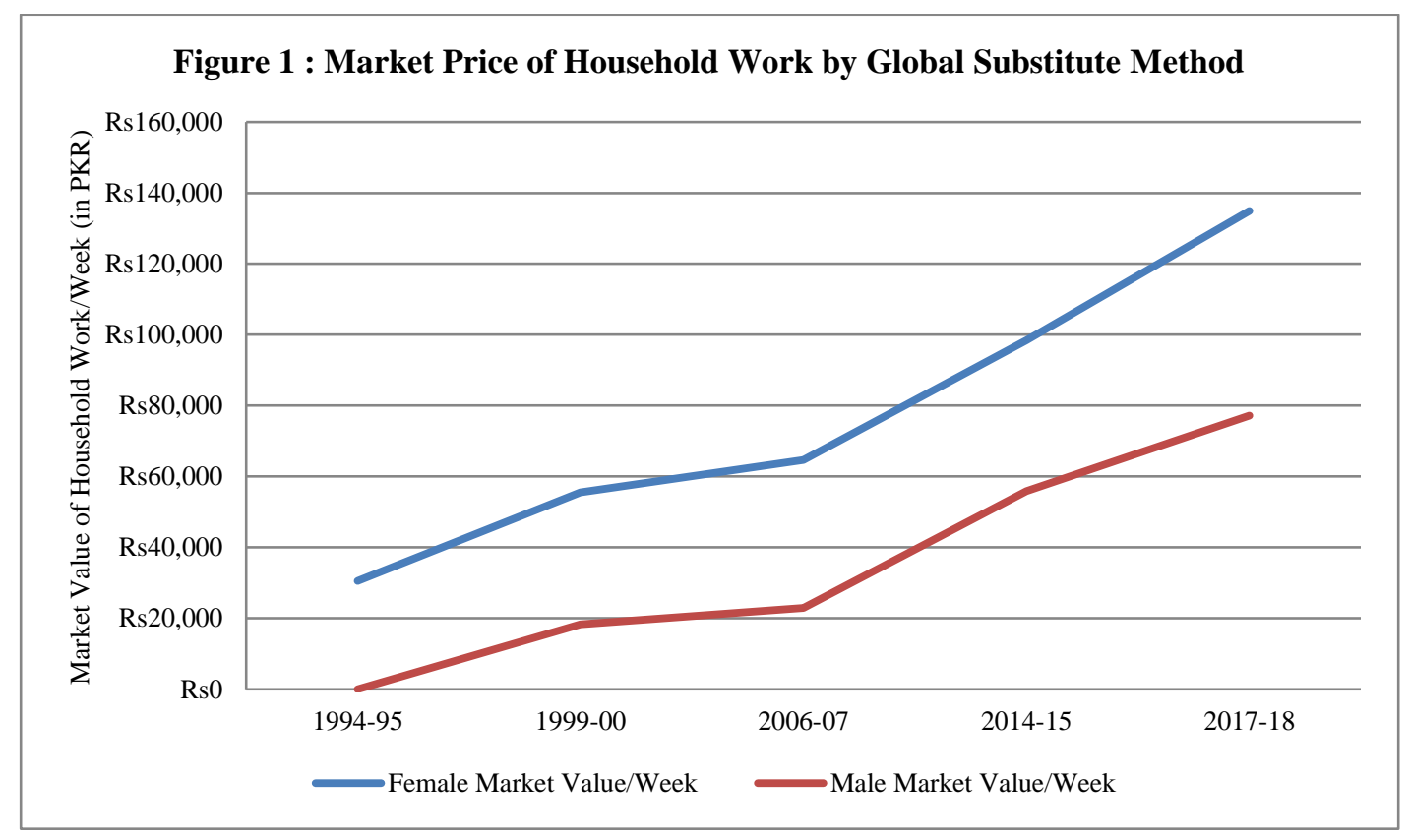

Market value is estimated by the time individual spend on each type of non-market activity with their respective market wages matched with their specialized activity. From figure 2 once again it is obvious that the market value of activities such as child care and cooking is higher as compared to other non-market activities as said earlier these activities are time-consuming, therefore their market price is also higher. Though, the market price of all non-market activities has increased over the years. The market 
value of sewing has increased from Rs.2,500/week to Rs. 6,718/week, for washing and house cleaning it, has increased from Rs.5,367/week to Rs.12,600/week and Rs. 2,282/week to Rs. 12,627/week respectively, for child care and child education it has increased from Rs. 2,407/week to Rs. 24,340/week and Rs.5,438/week to Rs. $13,819 /$ week and for cooking it has increased from Rs. 7,081/week to Rs. 41,778/week.

For males, the market value of shopping and marketing has increased from Rs.3,867/week to Rs.19,762/week and for females, it has increased from Rs.1,349/week to Rs.12,394/week, for firewood collection it has increased for males from Rs.5,326/week to Rs.24,304/week and for females from Rs.2,583/week to Rs.3,264/week, for fetching water it has increased for males from Rs.4,959/week to Rs.22,369/week and for females from Rs.2,153/week to Rs.4,087/week and for construction work, it has increased from Rs.4,109/week to Rs.10,767/week for males and for females it has increased from Rs.1,971/week to Rs.10,657/week. As compared to other household activities market price of the male is higher for firewood collection. Since, it is necessary for household consumption, especially in rural and underdeveloped areas.

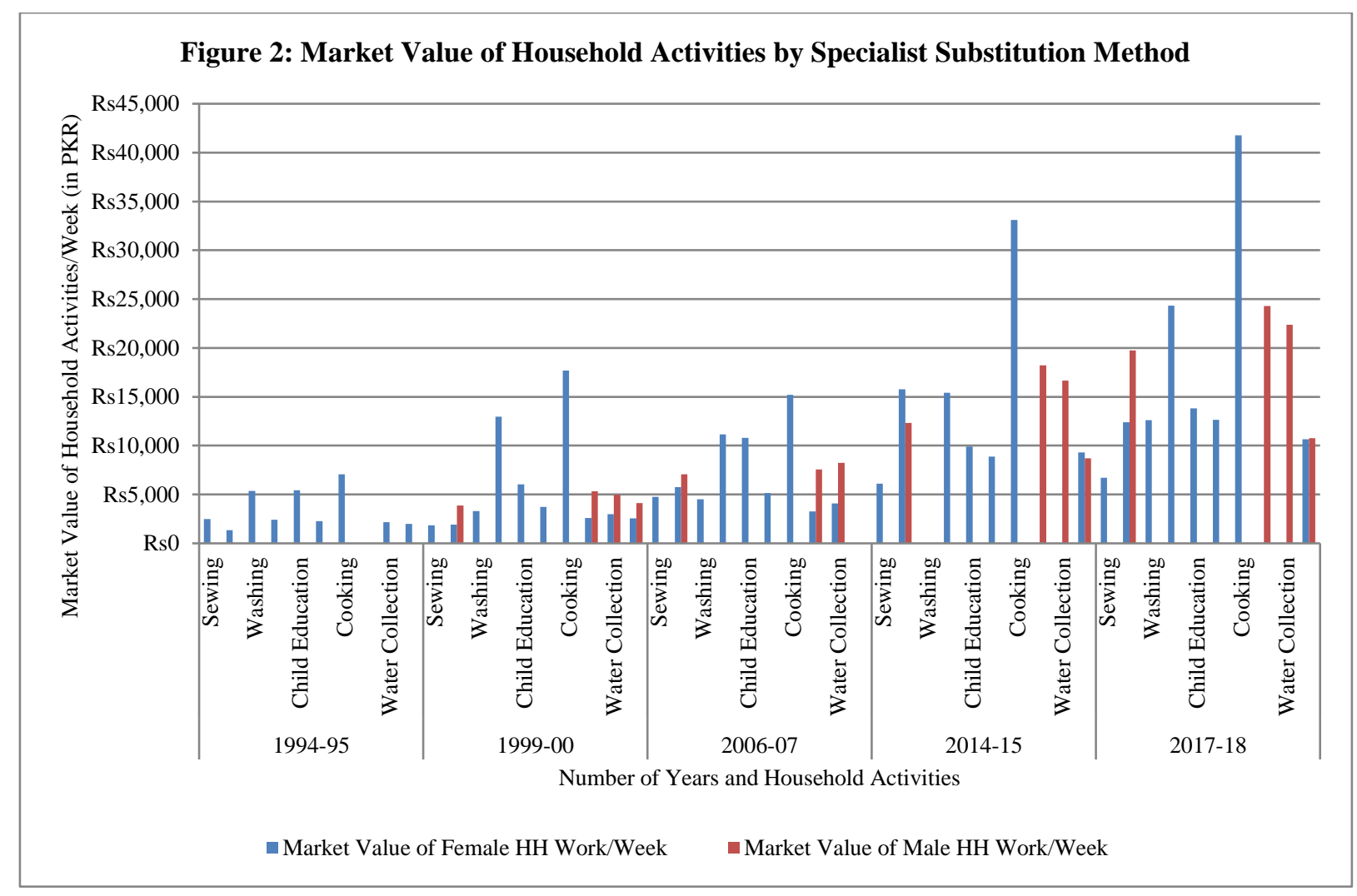

It is obvious from the above-mentioned figure and tables that the opportunity cost of all non-market activities is greater than the market value since opportunity cost is 
Journal of Applied Economics and Business Studies, Volume. 4, Issue 4 (2020) 135-160 https://doi.org/10.34260/jaebs.447

estimated by using minimum wage criteria and market value is estimated by using the actual market price of the activities.

\section{b. Empirical Results}

The empirical assessment of factors accelerating the opportunity cost and market price of non-market work as discussed in equations (I) and (II) and are presented in Tables 3 and 4. In table 3 determinants of the opportunity cost of household work by both gender is discussed and it shows that with the increase in age opportunity cost has increased. In Pakistan, women's work starts early in life and continues till the sixties or late. Girls in teens besides giving time to their studies also help their mothers in domestic chores. Whereas, males perform the household activities in their teens, and with the increase in their age its opportunity cost declines as in traditional society they are responsible for supporting their family by engaging themselves in paid employment. However, age square explores the non-linearity which shows that as the age doubles, the opportunity cost of female household work decreases as their work is shared by young females of the household. As the years of education increase, the opportunity cost of female housework also increases. Women are either highly qualified or illiterate their participation in the labour market remains low as in traditional society household work is mandatory for them, hence opportunity cost of their non-market work is higher. Besides household responsibilities the factors which hinder their participation in the labour market are gender discrimination, job mismatch, two-tiers labor market in Pakistan, lower remuneration offered, glass ceiling, etc. An additional year of female education will increase the opportunity cost of her household work by Rs.98.3/week. Female either being married or widow/divorced have a positive and significant effect on the opportunity cost as it is the prime responsibility of female to fulfill the household chores. Male either being married or divorced has a negative and significant effect on opportunity cost as they have higher paid market hours and are responsible for fulfilling household expenses which leads to a decline in their household work. The opportunity cost of married and widow/divorced female increases by Rs.3,005/week and Rs.1,610/week; whereas the opportunity cost of married and widow/divorced male decreases by Rs.1,564/week and Rs.2,401/week respectively.

An increase in the number of dependent in a household increases the opportunity cost of female household work as the dependents require more care and nurturing. Further, they have higher responsibilities of childbearing, rearing, and taking care of adults especially if they are sick. According to Arshad (2008) women have taken most of the household responsibilities without a helping hand. If they hire a maid, still cooking, up-bringing of children, and assessing them with the school homework is usually done by female households. The increase in the number of children under the age of 6, age 6-10, and age 11-14 increases the opportunity cost of female housework by Rs. 104.5, Rs.91.8, and Rs.135/week, whereas an increase in the number of adults increases the opportunity cost of female work by Rs.286/week. The opportunity cost of 
Hamna Nasir, Ambreen Fatima and Shaista Alam

non-market work is higher in the urban region because due to the change in the urban lifestyle, increase in the nuclear family setup, and vilest social conditions women prefer to perform most of the household chores by themselves. As compared to rural regions opportunity cost of females residing in urban regions increases by Rs.449.7/week. As compared to KPK opportunity cost of females residing in Punjab increases by Rs.3,424/week, whereas the opportunity cost of females residing in Sindh and Baluchistan decreases by Rs.224/week and Rs.239/week. The opportunity cost of males residing in Punjab, Sindh, and Baluchistan decreases by Rs.3,809/week, Rs.3,488/week, and Rs.2,433/week respectively. It depends on the cultural norms and traditions of the province that the opportunity cost of non-market for both gender is higher in some provinces and lower in others. As compared to other provinces most of the household chores are performed by females in Punjab due to its tradition which leads to an increase in the opportunity cost of their work. All non-market activities and year dummies have a positive and significant effect on the opportunity cost of household work. Finally, the value of $\mathrm{R}^{2}$ for the opportunity cost of non-market work for males and females is $39.2 \%$ and $54.4 \%$ respectively.

Table 3: Determinants for Economic Value of Household Work

\begin{tabular}{|c|c|c|}
\hline Dependent Variable: Economic Value (in PKR/Week) & Female Coefficient & Male Coefficient \\
\hline \multicolumn{3}{|l|}{ Personal Characteristics } \\
\hline \multirow[t]{2}{*}{ Age } & $248.0 * * *$ & $187.1 * *$ \\
\hline & $(7.329)$ & $(91.21)$ \\
\hline \multirow[t]{2}{*}{$\mathrm{Age}^{2}$} & $-4.079 * * *$ & -1.625 \\
\hline & $(0.0936)$ & $(1.076)$ \\
\hline \multicolumn{3}{|l|}{ Education } \\
\hline \multirow[t]{2}{*}{ Education in Years } & $98.34 * * *$ & 111.6 \\
\hline & $(4.665)$ & $(68.99)$ \\
\hline \multicolumn{3}{|l|}{ Marital Status Dummy } \\
\hline \multirow[t]{2}{*}{ Married } & $3,005 * * *$ & $-1,564 *$ \\
\hline & $(55.89)$ & $(851.7)$ \\
\hline \multirow[t]{2}{*}{ Widow \& Divorced } & $1,610 * * *$ & $-2,401 *$ \\
\hline & $(99.66)$ & $(1,247)$ \\
\hline \multicolumn{3}{|l|}{ Socio Demographic Characteristics } \\
\hline \multirow[t]{2}{*}{ Number of children under 6 years } & $104.5 * * *$ & 296.8 \\
\hline & $(11.77)$ & $(188.7)$ \\
\hline \multirow[t]{2}{*}{ Number of children of age $6-10$ years } & $91.80 * * *$ & 61.18 \\
\hline & $(14.41)$ & $(234.4)$ \\
\hline \multirow[t]{2}{*}{ Number of children of age11-14 years } & $135.0 * * *$ & 218.6 \\
\hline & $(18.70)$ & $(306.3)$ \\
\hline \multirow[t]{2}{*}{ Number of adults above 65 years } & $286.2 * * *$ & 327.2 \\
\hline & $(35.82)$ & $(547.9)$ \\
\hline \multirow[t]{2}{*}{ Household Income (in PKR/Week) } & 0.00562 & -0.0170 \\
\hline & $(0.00362)$ & $(0.0476)$ \\
\hline Region Dummy & & \\
\hline
\end{tabular}

152 
Journal of Applied Economics and Business Studies, Volume. 4, Issue 4 (2020) 135-160 https://doi.org/10.34260/jaebs.447

\begin{tabular}{|c|c|c|}
\hline Dependent Variable: Economic Value (in PKR/Week) & Female Coefficient & Male Coefficient \\
\hline \multirow{2}{*}{ Urban Region } & $449.7 * * *$ & -2.102 \\
\hline & $(33.00)$ & $(549.5)$ \\
\hline \multicolumn{3}{|l|}{ Province Dummy } \\
\hline \multirow{2}{*}{ Punjab } & $3,424 * * *$ & $-3,809 * * *$ \\
\hline & $(42.18)$ & $(623.6)$ \\
\hline \multirow[t]{2}{*}{ Sindh } & $-224.3 * * *$ & $-3,488 * * *$ \\
\hline & $(45.52)$ & $(748.9)$ \\
\hline \multirow[t]{2}{*}{ Baluchistan } & $-238.7 * * *$ & $-2,433 * *$ \\
\hline & $(54.22)$ & $(1,047)$ \\
\hline \multicolumn{3}{|l|}{ Household Activities Dummy } \\
\hline \multirow[t]{2}{*}{ Firewood Collection } & $1,633 * * *$ & $3,182 * *$ \\
\hline & $(195.7)$ & $(1,258)$ \\
\hline \multirow[t]{2}{*}{ Fetching Water } & $3,778 * * *$ & $2,395^{*}$ \\
\hline & $(187.5)$ & $(1,279)$ \\
\hline \multirow[t]{2}{*}{ Shopping and Marketing } & $-2,762 * * *$ & $3,128 * * *$ \\
\hline & $(167.5)$ & $(1,109)$ \\
\hline \multirow[t]{2}{*}{ Sewing } & $1,783 * * *$ & - \\
\hline & $(166.9)$ & \\
\hline \multirow[t]{2}{*}{ Washing\& Pressing Clothes } & $3,576 * * *$ & - \\
\hline & $(161.1)$ & \\
\hline \multirow[t]{2}{*}{ Child Care/Adult Care } & $13,753 * * *$ & - \\
\hline & $(163.3)$ & \\
\hline \multirow[t]{2}{*}{ Child Education } & $2,791 * * *$ & - \\
\hline & $(185.5)$ & \\
\hline \multirow[t]{2}{*}{ House Cleaning } & $5,580 * * *$ & - \\
\hline & $(161.1)$ & \\
\hline \multirow[t]{2}{*}{ Cooking } & $23,127 * * *$ & - \\
\hline & $(161.4)$ & \\
\hline \multicolumn{3}{|l|}{ Year Dummy } \\
\hline \multirow[t]{2}{*}{1999} & $1,982 * * *$ & - \\
\hline & $(60.01)$ & \\
\hline \multirow[t]{2}{*}{2006} & $6,195 * * *$ & $1,959^{* *}$ \\
\hline & $(52.08)$ & $(791.3)$ \\
\hline \multirow[t]{2}{*}{2014} & $23,320 * * *$ & $11,631 * * *$ \\
\hline & $(52.83)$ & $(868.7)$ \\
\hline \multirow[t]{2}{*}{2017} & $29,714 * * *$ & $15,383 * * *$ \\
\hline & $(52.32)$ & $(834.5)$ \\
\hline Constant & $\begin{array}{c}-12,087 * * * \\
(194.6)\end{array}$ & $\begin{array}{c}521.5 \\
(1,873)\end{array}$ \\
\hline F-Statistics & $\begin{array}{c}38449.31^{*} \\
(0.0000) \\
\end{array}$ & $\begin{array}{c}41.67^{*} \\
(0.0000)\end{array}$ \\
\hline Observations & 869,408 & 1,312 \\
\hline R-squared & 0.544 & 0.392 \\
\hline
\end{tabular}


Table 4 shows the determinants of the market price of household work by genders as outline in equation II. Results show that with the increase in age market price has increased. Women work in the market as a domestic helper and their participation usually starts from early life. Those girls who do not attend school help their mothers as domestic helpers or fulfill domestic responsibilities and look after their siblings by paying the penalty of not attending school. Whereas, males are engaged in only those activities which are necessary for household consumption, and these activities are outsourced only in higher-income families. However, age square exploring the nonlinearity shows that as the age doubles, the market value of female household work decreases as after a certain age their work is shared by a new generation as said earlier. Further, as the years of education increases market price of female housework also increases as educated female will/may make use of their education and participate in labour market; therefore some household activities may be outsourced. An additional year of education will increase the market price of female work by Rs. 40.6/week. Female either being married or widow/divorced may have a positive and significant effect on the market price of her household work, whereas male being married has a negative and significant effect on the market value of his household work. The market value of married and widow/divorced females is higher because in order to support their families they work as domestic helpers. Further, the market value of women's work may also have increased as in rural or pari urban areas mostly males have seasonal income or they often do not participate in labour market and hence depend on the wages of their spouse. If the women participate in paid market work they usually hire maids to perform mundane tasks or depends on their daughters to support them. If Widow/divorced females are from lower-income family then besides performing market work she also has to perform her own domestic work which leads to an increase in the opportunity cost and market price of her work. After marriage responsibilities of male increases therefore they will search for better employment opportunities to earn a better livelihood instead of participating in lower-paid occupation. The market price of married and widow/divorced females increases by Rs.1,375/week and Rs.708/week; whereas the market price of married males decreases by Rs.705/week. As the number of children under the age of 6 years and the number of adults above the age of 65 years increases in a household then the market price of non-market work also increases as the dependents require proper care and attention which leads to an increase in the market price of female work. An increase in the number of children under the age of 6 , children between the age of 6-10, and children between the age of 11-14 increase the market price of female work by Rs.50, Rs.39, and Rs.62.68/week, whereas an increase in the number of adults increases the market price of female work by Rs.134.8/week. As compared to rural regions females dwellers of the urban region have a positive and significant effect on market price as prices of these activities are higher in urban areas. The market price of female work in urban regions increase by Rs.215/week. Further, most of the females are engaged in paid market work and change in urban lifestyle especially of higher-income 
families has increased the hiring of maids. Female households who have lower income are double burdened as besides performing the domestic duties they are also engaged in market work as domestic helpers. The market cost of females residing in Punjab may increase by Rs.1,503/week. Whereas the market price of females residing in Sindh and Baluchistan may decrease by Rs.128.5/week and Rs.69.9/week. The market value of males residing in Punjab, Sindh, and Baluchistan decreases by Rs.1,747/week, Rs.1,617/week, and Rs.1,127/week. Non-market activities and year dummies show that the effect of all non-market activities has a positive and significant effect on the market value of female household work except shopping and marketing as there are fewer female who performs this activity or it is mostly performed by male household members, whereas the effect of all household activities has a positive and significant effect on the market price of male household work. Year dummies have both positive/negative effect on the market price. The value of $\mathrm{R}^{2}$ for the market price of nonmarket work for males and females is $26.9 \%$ and $50 \%$ respectively.

Table 4: Determinants of Market Price for Household Work

\begin{tabular}{|c|c|c|}
\hline Dependent Variable: Market Price(in PKR/Week) & Female Coefficient & Male Coefficient \\
\hline \multicolumn{3}{|l|}{ Personal Characteristics } \\
\hline \multirow[t]{2}{*}{ Age } & $119.3 * * *$ & $81.10 * *$ \\
\hline & $(3.128)$ & $(40.10)$ \\
\hline \multirow[t]{2}{*}{$\mathrm{Age}^{2}$} & $-1.937 * * *$ & -0.698 \\
\hline & $(0.0400)$ & $(0.473)$ \\
\hline \multicolumn{3}{|l|}{ Education } \\
\hline \multirow[t]{2}{*}{ Education in Years } & $40.60 * * *$ & 48.30 \\
\hline & $(1.991)$ & $(30.33)$ \\
\hline \multicolumn{3}{|l|}{ Marital Status Dummy } \\
\hline \multirow[t]{2}{*}{ Married } & $1,375^{* * *}$ & $-705.1 *$ \\
\hline & $(23.86)$ & $(374.5)$ \\
\hline \multirow[t]{2}{*}{ Widow \& Divorced } & $708.3 * * *$ & -833.8 \\
\hline & $(42.53)$ & $(548.5)$ \\
\hline \multicolumn{3}{|l|}{ Socio Demographic Characteristics } \\
\hline \multirow[t]{2}{*}{ Number of children under 6 years } & $50.00 * * *$ & $142.1 *$ \\
\hline & $(5.021)$ & $(82.98)$ \\
\hline \multirow[t]{2}{*}{ Number of children of age $6-10$ years } & $39.44 * * *$ & 40.23 \\
\hline & $(6.151)$ & $(103.1)$ \\
\hline \multirow[t]{2}{*}{ Number of children of age 11-14 years } & $62.68 * * *$ & 83.47 \\
\hline & $(7.983)$ & $(134.7)$ \\
\hline \multirow[t]{2}{*}{ Number of adults above age 65 years } & $134.8 * * *$ & 106.7 \\
\hline & $(15.29)$ & $(240.9)$ \\
\hline \multirow[t]{2}{*}{ Household Income (in PKR/Week) } & 0.00244 & -0.00939 \\
\hline & $(0.00154)$ & $(0.0209)$ \\
\hline \multicolumn{3}{|l|}{ Region Dummy } \\
\hline \multirow[t]{2}{*}{ Urban Region } & $215.2 * * *$ & 86.99 \\
\hline & $(14.09)$ & $(241.6)$ \\
\hline \multicolumn{3}{|l|}{ Province Dummy } \\
\hline Punjab & $1,503 * * *$ & $-1,747 * * *$ \\
\hline
\end{tabular}


Hamna Nasir, Ambreen Fatima and Shaista Alam

\begin{tabular}{|c|c|c|}
\hline Dependent Variable: Market Price(in PKR/Week) & Female Coefficient & Male Coefficient \\
\hline & $(18.00)$ & $(274.2)$ \\
\hline \multirow[t]{2}{*}{ Sindh } & $-128.5 * * *$ & $-1,617 * * *$ \\
\hline & $(19.43)$ & $(329.3)$ \\
\hline \multirow[t]{2}{*}{ Baluchistan } & $-69.91 * * *$ & $-1,127 * *$ \\
\hline & $(23.14)$ & $(460.3)$ \\
\hline \multicolumn{3}{|l|}{ Household Activities Dummy } \\
\hline \multirow[t]{2}{*}{ Firewood Collection } & $902.0 * * *$ & $1,429 * * *$ \\
\hline & $(83.52)$ & $(553.2)$ \\
\hline \multirow[t]{2}{*}{ Fetching Water } & $1,925 * * *$ & $1,106^{* *}$ \\
\hline & $(80.02)$ & $(562.4)$ \\
\hline \multirow[t]{2}{*}{ Shopping and Marketing } & $-975.8 * * *$ & $1,291 * * *$ \\
\hline & $(71.48)$ & $(487.4)$ \\
\hline \multirow[t]{2}{*}{ Sewing } & $973.2 * * *$ & - \\
\hline & $(71.26)$ & \\
\hline \multirow[t]{2}{*}{ Washing\& Pressing Clothes } & $1,882 * * *$ & - \\
\hline & $(68.77)$ & \\
\hline \multirow[t]{2}{*}{ Child Care/Adult Care } & $6,503 * * *$ & - \\
\hline & $(69.70)$ & \\
\hline \multirow[t]{2}{*}{ Child Education } & $1,596 * * *$ & - \\
\hline & $(79.17)$ & \\
\hline \multirow[t]{2}{*}{ House Cleaning } & $2,837 * * *$ & - \\
\hline & $(68.76)$ & \\
\hline \multirow[t]{2}{*}{ Cooking } & $10,821 * * *$ & - \\
\hline & $(68.88)$ & \\
\hline \multicolumn{3}{|l|}{ Year Dummy } \\
\hline \multirow[t]{2}{*}{1999} & $3,693 * * *$ & - \\
\hline & $(25.61)$ & \\
\hline \multirow[t]{2}{*}{2006} & $3,045 * * *$ & $-783.6 * *$ \\
\hline & $(22.23)$ & $(347.9)$ \\
\hline \multirow[t]{2}{*}{2014} & $8,852 * * *$ & $2,413 * * *$ \\
\hline & $(22.55)$ & $(381.9)$ \\
\hline \multirow[t]{2}{*}{2017} & $11,516 * * *$ & $3,962 * * *$ \\
\hline & $(22.33)$ & $(366.9)$ \\
\hline \multirow[t]{2}{*}{ Constant } & $-5,018 * * *$ & $2,726 * * *$ \\
\hline & $(83.05)$ & $(823.6)$ \\
\hline F-Statistics & $\begin{array}{c}32256.48^{*} \\
(0.0000)\end{array}$ & $\begin{array}{c}23.79^{*} \\
(0.0000)\end{array}$ \\
\hline No. of Observations & 869,408 & 1,312 \\
\hline R-squared & 0.500 & 0.269 \\
\hline
\end{tabular}

\section{Conclusion and Policy Implications}

In this study opportunity cost and market price of household work by gender and for different type of household activities have been estimated and explored in detail. The opportunity cost of male and female household work was found out to be Rs.26,082/week and Rs.155,126/week respectively; whereas market price of male and 156 
female is found out to be Rs.22,098/week and Rs.63,813/week respectively. The opportunity cost and market price of child care and cooking activity is higher as compared to other household activities if it is performed by females. Whereas, the opportunity cost of shopping and marketing and firewood collection is higher as compared to other activities if performed by males. As these activities are necessary for household consumption and are performed outside the house and it mostly increases when paid market hours of male work decreases as these activities are mostly performed by male residents of rural and pari-urban areas. Moreover, opportunity cost and market price is higher in those regions where the patriarchal system and veiling factors are still being practiced.

Married and widow/divorced females have a positive and significant effect on the opportunity cost and market price of their household work, whereas married males have a negative effect on the opportunity cost and market price of their household work. Since it is the prime responsibility of a female to fulfill the household chores whatever her marital status is, whereas married males are responsible to support their families which increases their paid market hours leading to decline in their non-market hours. In the presence of dependents, the opportunity cost of non-market work may increase the domestic responsibilities of the female; whereas the market value of non-market work increases therefore maids are hired to assess females to fulfill other domestic duties. Female residents of Punjab have a positive and significant effect on the opportunity cost and market price of their household work, whereas female residents of Sindh and Baluchistan have a negative and significant effect on the opportunity cost and market price of their household work. Male residents of all provinces have a negative and significant effect on the opportunity cost and market price of their household work. Hence the increase and decrease in the opportunity cost and market price depend on the cultural norms and traditions of the province as well as on the socio-economic condition of the households.

In this study, the emphasis on monetary value is given to highlight the contribution made by women to society. No society can function with the only economic side of life. The most important activity in society is maintaining a household and nurturing its members. Women work with affection for their family members so money cannot buy such affection. Society would crumble without the daily tasks of caring, nurturing, and supporting others. An economic value of non-market work is assigned not to undervalue it, but to remind ourselves that even in the male world of economics; women make an essential contribution as their work has substantial economic value, hence it should be recognized.

Women can be seen as subsidizing salaries throughout the workforce, by contributing to domestic work freely rather than demanding a wage. It is vital that officials and others recognize that expenditures on women, whether in the home or at the national level are not a drain or an expense, but rather an investment in the economic 
and social welfare of the country. It is recommended that women's housework should be valued at the national level as they contribute by taking care of their homes, save their family money and support their family in multiple ways and in this way target set in SDG goal 5.4 can be achieved. It would help in raising the status of women and promote gender equality in Pakistan by ultimately reducing poverty and dependency which is faced by many women. By changing the perceived value of women would change the way policymakers approach programs to assess women. As women's work is given value in India and Vietnam, if their work is given value by the Government of Pakistan then men would have a better understanding of their value, give importance their work and they would likely treat them with more respect. Thus, it would be easier to create happier, mutually respectful, and violence-free families. If policymakers and others wish to see more women entering the formal economy they often forget that women who take on a paid job are required to do double duty as they would remain the sole or main responsible person for domestic duties. A society that respects and values the care work for others would also be far more humane than one that values paid jobs.

\section{References}

Alian Girard (1958). 'The time budget of married women in urban agglomerations', Population, October-December 1958.

Ann Chadeau (1992). 'What is Households' Non-Market Production Worth?', OECD Economic Studies No. 18 Spring 1992, pp.1-19.

Ayesha Khan (2007), 'Pathways of Women's Empowerment South Asia Programme, Pakistan Scoping Paper', Collective for Social Science Research.

Bhalotra, S., \& Attfield, C. (1998), 'Intrahousehold resource allocation in rural Pakistan: a semiparametric analysis', Journal of Applied Econometrics, 13(5), pp.463-480.

Becker, G.S. (1965) "A Theory of the Allocation of Time," Economic Journal, 75, pp. 493-517.

Becker, G. S. (1985). 'Human Capital, Effort, and the Sexual Division of Labor', Journal of Labor Economics, 3(1), pp. 33-58.

Bell, Edward B and Taub, Allan J. (1982). 'The Value of Household Services', American Journal of Economics and Sociology, 41, pp. 214-218.

Chiswick, Carmel. (1982). 'The Value of a Housewife's Time', Journal of Human Resources, 17, pp. 413-425. 
Journal of Applied Economics and Business Studies, Volume. 4, Issue 4 (2020) 135-160 https://doi.org/10.34260/jaebs.447

Debra Efroymson (2010). 'Women, Work and Money: Studying the Economic Value of Women's Unpaid Work and using the results of Advocacy', Report by Health Bridge and the Institute of Social Development Studies.

Folbre, Nancy (2009). 'Valuing Unpaid Work Matters, Especially for the Poor', New York Times online, September 21, 2009.

Fourastii, J., Les (1965)، ‘40.000 hours’,Laffont, Paris, 1965.

Hamdad, M. (2003). 'Valuing Households' Unpaid Work in Canada, 1992 and 1998: Trends and Sources of Change', Presented at Statistics Canada Economic Conference in May 2003.

Hamid Shamim (1996). 'Why Women Count, Essays on Women in Development in Bangladesh', TheUniversity PressLimited.

Harvey James (1996). 'The Valuation of Household Production: How Different are the Opportunity Cost and Market Price Valuation Methods?', Presented at Workshop of Brigham Young University.

Hawrylshyn (1976). 'The Value of Household Services: A Survey of Empirical Estimates', The Review of Income and Wealth, 22 (2), pp.101-103

Hawrylshyn (1977). 'Towards a definition of Non-Market Activities', Review of Income and Wealth, 23 (1), pp.79-96.

Heymann, J and C Beem, Ed. (2005).'Unfinished Work, Building Equality and Democracy in an Era of Working Families', The New Press.

Margaret Reid (1934). 'Economics of Household Production', John Wiley \& Sons Inc.

Marianne A. Ferber and Bonnie G. Birnbaum (1980). 'Housework: Priceless or Valueless', Review of Income and Wealth, 26 (4), pp.387-400.

Michel, Andrke (1978). ‘Women in Merchant Society’, University Press of France 1978.

Murphy, Martin (1978). 'The Value of Nonmarket Household Production: Opportunity Cost Versus Market Cost Estimates', The Review of Income and Wealth, 24, pp.243-256.

Najam-us-Saqib, \& Arif, G. M. (2012), "Time Poverty, Work Status and Gender: The Case of Pakistan", Pakistan Development Review, Vol.51 (1),pp. 23-46.

Naqvi, Z. F., Shahnaz, L., \& Arif, G. M. (2002). 'How do women decide to work in Pakistan'?, The Pakistan development review, 41 (4), pp. 495-513

Pandey (2001). 'Women's Contribution to the Economy through their Unpaid Labor', Working Papers from National Institute of Public Finance and Policy, pp.1-33

Peterson, R. D. (1978). 'Problems in Estimating the Value of Household Services', American Journal of Economics and Sociology, 37, pp.145-148. 
Quah, Euston (1986). 'Persistent Problems in Measuring Household Production: Definition, Quantifying Joint Activities and Valuation Issues are Solvable',American Journal of Economics and Sociology,45, pp.235-245.

Statistics Canada (1995). 'Households' Unpaid Work: Measurement and Valuation',Studies in National Accounting, Catalogue 13-603E. No 3.

Stoetzel Jean (1948).'A study of the Budgeting of Time by Womenin Urban Communities', Population 3(1), January-March 1948, pp.47-62.

Sultana, N., Nazli, H., Malik, S. J., \& Kazi, S. (1994), "Determinants of female time allocation in selected districts of Rural Pakistan", Pakistan Development Review, Vol.33 (2), pp. 1141-1153

Syed, J., Pio, E., \& Ali, F. (2013), 'A multi-level perspective on equal employment opportunity for women in Pakistan. Equality, Diversity and Inclusion', An International Journal, 32 (3), pp. 289-309.

Szalai Alexander (1972). 'The Use of Time: Daily Activities of Urban and Sub-Urban Population in Twelve Countries', The Hague: Mouton\& Co 1972.

Wolf, Robert (1986). 'Assessing the Value of Household Services: Three Methods', Trial, 22, pp.81-83.

Zehra Arshad (2008). 'The Economic Contribution of Pakistani Women through their Unpaid Labor', Report by Society for Alternative Media and Research and Health Bridge 2007. 